\title{
ARISTOPHANES' NACHLEBEN AND OTHER POST-RENAISSANCE DISASTERS*
}

\author{
Francois Pauw (University of Stellenbosch)
}

\section{Introduction}

\begin{abstract}
Well I will scourge those apes
And to these courteous eyes oppose a mirrour

As large as is the stage, whereon we act:

Where they shall see the times deformitie

Anatomiz'd in every nerve and sinnew,

With constant courage and contempt of fear.
\end{abstract}

(Ben Jonson, Every Man out of His Humour, Induction, 117-122)

It is a truism that most subgenres of western comedy since the Renaissance are much more indebted to the Roman New Comedy playwrights Plautus and Terence-and, implicitly, to their Athenian predecessor, Menander ${ }^{1}$-than to the Athenian triad of Old Comedy poets Aristophanes, Kratinos and Eupolis in the latter half of the fifth century B.C. ${ }^{2}$ The Renaissance predilection for New Comedy models has proved to

This article is dedicated to Prof. Pieter Conradie, whose lifelong interest, as mentor and author, in classical Greek tragedy and its nachleben has stimulated my own interest in this field. Now that he and his peers have lost their Faculties, this article, albeit decidedly untragic in subject matter, could serve to reassure him that Greek drama is still sending intertextual echoes through the ages.

1 With a view to contrast them with Aristophanes, the three post-classical poets Menander, Plautus and Terence are provisionally lumped together as authors of a subgenre called New Comedy. This is not to deny that there are important differences between these three poets with respect to, e.g., originality of plot, unity of plot, depth of characterisation, or the depiction of women (for which see Castellani 1988; Dobrov 1988; Anderson 1995), or that Terence is Menander's proper heir in terms of 'serious' comedy, whereas Plautus contains much more slapstick, farce, sexual innuendo, fantasy, and metatheatrical games. My purpose here is primarily to differentiate between elements common to Greek and Roman New Comedy and its post-Renaissance successors, on the one hand, and Old Comedy, on the other. In view of the paucity of extant Greek New Comedy plays in unfragmented form (one by Menander; none by his colleagues Philemon and Diphilos), 'New Comedy' will mostly refer to Roman New Comedy.

2 The triad of Old Comedy poets has been cenonised by Horace (Sat. 1.4): Eupolis atque Cratinus Aristophanesque poetae ... mulla cum libertase notaban ("The poets Eupolis and Cratinus and Aristophanes ... branded [their victims] with much freedom of speech"). Since, however, Aristophanes is the only Old Comedy poet of whom unfragmented plays are extant, 'Aristophanes' and 'Old Comedy' will be used interchangeably in the discrssion that follows, and his preference for political themes will be taken as representative of Old Comedy. If the fragments of Aristophanes and his rivals are also considered, however, it becomes clear that other themes were also treated by Old Comedy poets. Kratinos, for instance, combined 
be so pervasive that Aristophanic plots, themes and stage conventions have, on the whole, been only very rarely imitated, adapted, satirised, or otherwise intertextually acknowledged.$^{3}$ Although the spirit of Aristophanes can still obliquely be recognised in twentieth-century media such as cabaret, cartoons and other forms of political satire, he has had no identifiable generic heir to keep the formal idiosyncrasies of Old Comedy alive. In contrast, New Comedy plays have been adapted innumerable times by playwrights since the Renaissance. ${ }^{4}$ In short, whereas specific plays of Menander, Plautus and Terence have often been consciously used as subtexts, Aristophanes' limited legacy has been more generally intertextual.

The unproductive intertextual nachleben of Aristophanes is reflected in the composition of courses on Comparative Comedy. Plautus' Amphitruo would provide a model for adaptations by Molière, Dryden and Giraudoux, to name but a few. In the case of the Menaechmi, the versions of Shakespeare (The Comedy of Errors) and Brink (Kinkels in die Kabel) merit comparison with the Plautine original. Terence's Andria can be compared with an subtextual heir such as Thornton Wilder's novella The Woman of Andros. In the case of Aristophanes, however, there is an embarrassing dearth of comparative material. No single post-Renaissance adapter of

mythological burlesque and political allegory in his Dionysalexandros (Dover 1987:206).

3 Racine, for example, borrowed the plot of Aristophanes' Wasps for the first part of his Les Plaideurs but added un-Aristophanic subplots (Slater 1988:86). Later, Shelley would attempt an Aristophanic farce-comedy, Oedipus Tyrannus or Swellfoot the Tyrant (1819), but it was a failure because "the form of Attic comedy was impossible to resuscitate" (Highet 1967:421). Even T.S. Eliot tried his hand at "fragments of an Aristophanic melodrama" called by the mock-tragic title Sweeney Agonistes, but failed to finish it (Highet 1967:504). On a more oblique level, authors such as Ben Jonson, Molière, Fielding in his Pasquin (Howarth 1978b:18-19) and George Bernard Shaw (Edmunds 1979:xl) could be regarded as heirs of Aristophanes in that their works have a 'corrective' force. The eclectic Jonson, especially, warrants comparison. Edmunds (1979:xxxix) argues that Jonson's works, though still within the convention of New Comedy, "had an affinity with Old Comedy in their deeply satirical and sardonic tone". In his discussion of Jonson's The Alchemist, Robert N. Watson (1986:364) observes that "the opening exchange of insults between Face and Subtle closely resembles an exchange in the Plutus of Aristophanes", and that "... through much of the play, Subtle seems to imagine he can take a standard Aristophanic role as an evil educator who is never punished for his knavery". Moreover, in his treatment of the Aristophanic parabasis, Thomas Hubbard (1991:231-240) provides an addendum on Jonsonian echoes of the Clouds parabasis. Even in Shakespeare, whose comedies are generally regarded as 'romantic', traces of Aristophanic influence have been detected. According to MacCary (1978:525-527), The Comedy of Errors is Aristophanic rather than Menandrian in tone and theme; Northrop Frye (quoted by Edmunds 1979:xxxv) regards Troilus and Cressida as a play "that falls within the genus of Old Comedy". In addition, Aristophanes appears as a character in Balaustion's Adventure by Robert Browning. In the last part of this mytho-historical dialogue, Aristophanes' Apology (1875), the Athenian girl Balaustion is portrayed as defending the merits of the deceased Euripides against Aristophanes. The latter, of course, argues for the superiority of his own genre (Berdoe $1891: 27-37)$.

4 For a discussion of the influence of Plautus and Terence upon English comedy (in part indirectly via Italian, German, or French playwrights), see Duckworth 1952:396-433. 
note has seen fit to resurrect the Aristophanic Socrates or Euripides in a genre cognate with Old Comedy.

Moreover, modern stage productions of Aristophanes' comedies, while remaining relatively popular, are usually pruned of late fifth-century allusions which are, quite correctly, perceived to be incomprehensible to non-classicists. Alternatively, as suggested by Geoffrey Chapman (1983:41-51), these allusions may be 'translated' into their modern equivalents. Such diachronic transposition, however, fails to solve the very problem of 'datedness' (i.e. chronological, geo-political and cultural specificity) which was created by Aristophanes in the first place. Let us take the example of Aristophanes' Knights, performed in 424 B.C. and containing a vitriolic attack on the populist politician Kleon. If Eugene Terreblanche, say, or Tony Yengeni were to be lampooned instead of Kleon, and if Aristophanes' chorus of Knights were to be represented by a present-day socio-economic equivalent such as Yuppies, it might work for a South-African audience in the nineteen-nineties, but it is likely to be lost on audiences outside South Africa, or once Yengeni and Yuppies have lost their topicality.

Such is the conundrum of lovers of Aristophanes. My object in this article is not to provide a solution for this dilemma, but to identify the factors which contributed to it, and to examine some of these. It is not difficult to find reasons for the limited nachleben of Aristophanes, as contrasted with New Comedy's productive nachleben.

A basic check-list should include at least the following:

1) The fortuitous nature of the transmission of texts from antiquity;

2) the generic preferences of literary critics in antiquity;

3) the cultural specificity of Aristophanes' characterisation of real individuals, in contrast with the universality of New Comedy character typology;

4) the idiosyncrasies of Aristophanes' 'narrative structure' (i.e. his outstanding plots and themes), in contrast with the accessibility of New Comedy love themes and suspense plots;

5) the formal idiosyncrasies of Aristophanes' plays (i.e. structural curiosities such as the agon and the parabasis, metrical variety, and the diverse functions of the chorus), in contrast with New Comedy's simpler structure of five acts separated by pro forma choral interludes;

6) the politicised nature of late Old Comedy, in contrast with the quotidian and domestic field of reference of New Comedy;

7) the extraordinary degree of comic licence allowed in democratised Old Comedy, in contrast with the New Comedy of republican Rome;

8) the frequency and extent of obscenity, particularly of a sexual and scatological nature, in Aristophanic plays ${ }^{5}$, in contrast with especially the decorous Terence, who appears positively moralising in his avoidance of indecencies;

9) the explicit didacticism of Aristophanes;

5 The standard work on Aristophanic obscenity remains Jeffrey Henderson's The Maculate Muse (1975). 
10) the prominence of the authorial persona in Old Comedy, especially in the parabasis and semi- or pseudo-parabatic passages;

11) the highbrow character of certain ironic intertextual games Aristophanes played with himself, his rivals, and his audience. 6

It should be clear that all but the first two of these factors are directly linked to the generic idiosyncrasies of Aristophanes; any discussion of my topic will thus necessitate free use of examples from Aristophanes' nine extant Old Comedy plays. ${ }^{7}$ In view of the fact that the twenty-seven extant New Comedy plays do not constitute as concise a corpus, discussion of New Comedy trends will be of a more general nature, less reference being made to examples from individual plays. Within the confines of an article such as this, not all of the above factors can be examined. I have opted for factors (3) and (4), since they seem to represent the very areas where the nachleben of Old Comedy versus New Comedy can best be contrasted. As a prelude, a brief look at factors (1) and (2) will serve to provide some historical background.

\section{Text transmission}

The first factor hampering Aristophanes' nachleben appears to be a mere matter of statistics: in the Renaissance, more copies of New Comedy than of Old Comedy were in circulation.

Today, 38 Graeco-Roman comedies (discounting mere fragments or titles) are extant: nine examples of Old Comedy by Aristophanes, his last two comedies belonging to fourth-century Middle Comedy; a single example of Greek New Comedy, Dyskolos (Old Cantankerous) by Menander; 20 fabulae palliatae by the Roman comic poet Plautus; ${ }^{8}$ and six by his successor Terence. The transmission of extant Graeco-Roman comedies thus betrays a clear bias in favour of New vis-à-vis Old Comedy: three playwrights against one; twenty-seven plays against nine. In the Renaissance the ratio between extant Old and New Comedy plays was virtually similar: only the manuscripts of Menander would have to wait till the twentieth century ${ }^{9}$ to complete the present tally of Graeco-Roman comedies. In the absence of Menander, New Comedy could thus be equated with Latin in the Renaissance; Old Comedy, of course, could be nothing but Attic Greek.

6 For a thorough, if occasionally over-subtle, treatment of (9), (10) and (11), see Hubbard 1991.

7 Since Aristophanes' last two extant plays are regarded as belonging to fourth-century Middle Comedy, I restrict myself to his nine extant Old Comedy plays, all of which were produced in the course of the Peloponnesian War.

8 In the second century A.D., Aulus Gellius recounted how these twenty Plautine plays, plus fragments of the Vidularia, had been canonised by Varro two centuries before him (Hunter 1985:5-6).

9 In 1907 Levèbre published a Menandrian papynus codex discovered at Aphroditopolis in Egypt, including sizeable parts of The Arbitration, The Rape of the Locks and the Samia. The Dyskolos Codex, undamaged but for 12 missing lines, was discovered in 1955 and published in 1958 (Dover 1987:218). 
How should one account for such a discrepancy in transmission between Old and New Comedy plays? It could, conceivably, be blamed on the vicissitudes of fortune. ${ }^{10}$ Alternatively, it could reflect the tastes of scribes and scholars in the transmission of texts from antiquity, whether in the Alexandrian library in Hellenistic times, in Christian monasteries, in centres of Arabic scholarship, or in Byzantine universities. 11

Even more important than these considerations, however, was the preponderance of Latin literature over Greek in the Renaissance. The Italian Renaissance, which was to provide a model for the rest of Europe, started with a rekindling of interest in things classical. Initially, however, Latin texts were more in vogue: they were more avidly read, discussed, translated and adapted than Greek texts. Since Italy was linguistically fragmented, “... the whole nation possessed the Latin poets as a common heritage; and on the ground of Plautus, Florentines and Neapolitans could understand each other" (J.S. Kennard, quoted in Highet 1967:135). Besides, there was much in common between the Italian commedia dell'arte and the spirit of Plautine comedy (Highet 1967:141).

The following example may help to account for the discrepancy between the popularity of Latin and Greek. In 1428 Nicholas Cusanus unearthed those twelve of Plautus' twenty comedies which had remained unknown during the dark ages, resulting in the old Roman plays, or their translations, being performed by scholars, courtiers and even church groups in Italy (Firth 1978:64). The revival of New Comedy in the sixteenth century under princely patronage was heralded by a performance of the Menaechmi in 1486, in the great courtyard of the Duke's palace at Ferrara (Levin 1986:132).

Thus Plautus was first translated into the vernacular at a relatively early stagefairly soon after the availability of the printing press. Highet (1967:121) provides the following landmark dates: 1511 (the first Plautine play translated into German), 1515 (Spanish) and 1595 (English). Terence, again, was first translated into German in 1486, into French in 1500, into Spanish in 1577 and into English in 1598 (Highet 1967:121-122). In the case of both Roman playwrights many other translations would soon follow.

10 This is no mere cliché. In some genres, the fortuitous survival of manuscripts is nothing short of miraculous. That Aristotle's later works, for example, are extant today, is due to a most serendipitous series of events (see Thomson 1965:13-15). In the case of comedy, however, the guardian angel of manuscript transmission has a poor track record. Eleven of Aristophanes' forty plays are extant, but no single play of the up to four hundred known to have been written by about fifty Old Comedy poets contemporary with him, has survived intact: they are known only as titles, or in fragmentary form (Dover 1972:1; Cartledge 1990:13). For Middle Comedy, Athenaios lists fifty-seven poets and approximately 800 plays; in the case of Greek New Comedy, we know of approximately sixty poets and 1400 plays.

11 R.L. Hunter (1985:2) remarks that the conditions for manuscript survival in very late antiquity and in the Byzantine period included "continued use as a school text, linguistic purity, historical interest, moral rectitude ...". 
Aristophanic plays, on the other hand (with the exception of Plutus), found few Renaissance translators, as did the Greek tragic poets. When applied to drama, especially tragic drama, the neglect of translations from the Greek is ascribed by Highet (1967:120) to factors such as the following: the extreme difficulty of the thought and language of Greek drama; the superior attraction of the more flamboyant Seneca; and the existence of handy Latin translations of Greek plays.

\section{Drama theory}

In the second place, in theories of comedy from antiquity to neoclassicism, Old Comedy continued to be regarded as "an Athenian idiosyncrasy outside the main development of the comic genre" (Anderson 1978:23). Consequently, transmitted drama criticism and commentaries favoured Latin comedies over Greek, as the following examples will illustrate. Horace's Ars Poetica, which had been available since antiquity, contains a reference to Old Comedy; ${ }^{12}$ however, this is merely in support of his theory that Old Comedy was somehow a remote ancestor of his own saturae. When Donatus' fourth-century commentary on Terence, which would accompany printed editions of Terence from 1471 onwards, was rediscovered in 1433 , interest in New Comedy was naturally stimulated-at the expense, at least implicitly, of Old Comedy. ${ }^{13}$

Aristotle's Poetics would become well-known in Italy only after Robortello and Maggi brought out their commentaries in 1548 and 1550 respectively (Firth 1978:64). Once again, however, this development would hardly contribute to an understanding of Old Comedy, since the Poetics is a study of tragedy and epic, 14 and what little the Stagirite had to say on literary comedy was primarily based on contemporary Middle Comedy; ${ }^{15}$ Aristophanes is referred to by name only once

12 Ars Poetica 281-284: Successit vetus hic comoedia non sine multa laude: sed in vitium liberas excidit, et vim dignam lege regi: lex est accepta: chorusque turpiter obticuit sublato iure nocendi. ("To these succeeded Old Comedy, not without considerable praise: but its personal freedom degenerated into excess and violence, worthy to be curbed by law; a law was made accordingly, and the chorus, on losing its right to be abusive, shamefully became silent.") This sentence, as well as the preceding and succeeding sentences in Horace, was later quoted by Donatus in his De Comoedia et Tragoedia, where, however, he fails to comment on the tendentious nature of Horace's generalisation concerning Athenian libel laws. Also cf. $B k .1$, Sat. 10; Serm. 1.4.1-5.

13 It should be noted that prior to the rediscovery of Donatus, debates on the function of drama were ill-informed. Thus a comedy was defined as "a narrative poem with a sad beginning and a happy ending", and accordingly Dante could call his great work Commedia (Hammond 1970:14).

14 As readers of Umberto Eco's The Name of the Rose will recall, Aristotle wrote a second Poetics (now lost) in which comedy was treated.

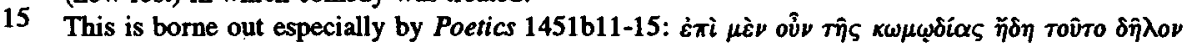

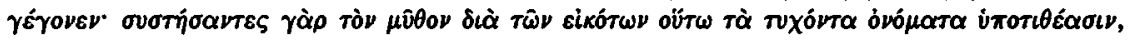

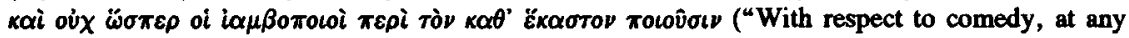
rate, this bas now become clear: by constructing a plot according to general probabilities, they [ = the comic poets] thus assign names arbitrarily; they refrain from dealing with an individual, as the iambic poets [did]"). 
(Poetics 1448a27). Thus, already for Aristotle, Old Comedy was so antiquated that he could define comedy in a way that altogether excludes it (Sommerstein 1978:10). Consequently, the neglect that Aristophanes fell prey to in terms of the limited number of extant Old Comedy texts by him as compared to those of Roman New Comedy (nine against twenty-six), or in terms of translations, was exacerbated by the limited impact of literary theory based on Old Comedy.

\section{Characterisation: type vs. individual}

Thirdly, in later ages drama spectators would find it easier to identify with New Comedy characters than with those of Old Comedy. The reason for this is that New Comedy characterisation is based virtually exclusively on types, whereas in Old Comedy character types are supplemented by the portrayal of historically identifiable individuals belonging to the late fifth century. ${ }^{16}$ The generic differentation between comic type and individual may be illuminated by a comparison with characterisation in tragedy. It is a truism that whereas the tragic is universal, the comic is chronologically and geographically more restricted by its subject matter and by the culture-specific nature of humour. The consequences, for the drama recipient, of such a distinction are formulated, albeit in exaggerated terms, by Umberto Eco (1987: 269-270):

It is an effort to find Aristophanes comic, and it takes more culture to laugh at Rabelais than it does to weep at the death of the Paladin Orlando ... Even without knowing the accusation against him, we suffer as Socrates dies slowly from the feet toward the heart, whereas without a degree in classics we don't know exactly why the Socrates of Aristophanes should make us laugh.

Eco's view on the inaccessibility of Old Comedy is substantially correct, but it would clearly require drastic modification to be applied to New instead of Old Comedy. ${ }^{17}$ In fact, if universality of impact were to be the only criterion, New Comedy would prove to be virtually the equivalent of tragedy. One of the reasons for such a correspondence is that Plautine and Terentian personae, like those of their Greek predecessor and model, Menander, tend to represent universal types rather than historical individuals. This can be deduced not only from an analysis of New

16 Rigid schematisation can be misleading. As W.D. Howarth (1978b:4) reminds us, most personae in New Comedy and its heirs are “... a quite subtle blend of the type-that a priori conception of the misanthrope, for example, which underlies both Menander's Knemon and Moliere's Alceste-and the individual, possessing those unique traits which distinguish Alceste from all other misanthropes, or which ensure that Jonson's Volpone is so much more than the embodiment of fox-like cunning."

17 This is borne out by the view of Howarth (1978b:5): "It is not so very unusual for us mentally to pigeonhole the more eccentric among our friends as 'a Falstaff' or 'a Harpagon', whereas we do not equally readily classify people as 'an Oedipus' or 'an Othello." The point is that the characteristics that typify Falstaff or Harpagon derive from New Comedy, not Old. 
Comedy character typology as manifested in the body of New Comedy plays, but also from the programmatic information in a number of prologues.

In Plautus' Menaechmi, for instance, the imagined adjustability of the stage residence is announced as follows (vv. 72-76):

Modo hic habitat leno, modo adulescens, modo senex, pauper, mendicus, rex, parasitus, hariolus.

(Sometimes a pimp resides here, sometimes a young man, and on occasion an old man, a poor man, a beggar, a king, a sponger, a soothsayer.)

Although it transpires that the play will involve a doctor rather than a soothsayer, and a prostitute instead of a procurer, the message is clear: the play will make use of stock types.

A generation later Terence would follow suit, as exemplified in the prologue of The Self-Tormentor, where the cast of characters is claimed to include the following (vv. 37-39):

... seruos currens, iratus senex, edax parasitus, sycophanta ... impudens, auarus leno.

(a running slave, angry old man, greedy sponger, shameless imposter, rapacious pimp.)

Similarly, in acknowledging his debt to Menander in the prologue of The Eunuch (vv. 36-38), Terence does so explicitly in terms of stock characters inherited from his Greek model, pleading that he should also be permitted

... currentem seruom scribere,

bonas matronas facere, meretricis malas,

parasitum edacem, gloriosum militem.

(to depict on a running slave, create virtuous wives and corrupt courtesans,

a greedy sponger and a braggart soldier.)

Stock types in New Comedy often had names which recurred in various other plays: a Daos, for instance (indicating a Phrygian background), figures in at least eight of the seventeen identifiable plays by Menander (Sandbach 1977:63). Alternatively, the nomenclature and titles of New Comedy and its heirs could express psychological traits (Levin 1986:30), Dyskolos and Le Misanthrope betraying irascibility ${ }^{18}$, and

18 For the productive nachleben of the misanthrope type from Menander's Knemon via Euclio in Plautus' Aulularia, to Shakespeare's Timon of Athens and Molière's Le Misanthrope, see Konstan 1983b:97-123. 
Heauton Timoroumenos masochism. A third category of New Comedy names, usually hapax legomena consisting of humorously exaggerated compounds, was based on etymology: no Roman versed in Greek would have failed to notice that Pyrgopolynices, the eponymous character of Plautus' Miles Gloriosus, was typified as 'Mighty Conquerer of Fortresses', or the parasite Artotrogus, aptly, as 'Bread-gobbler'.

Were New Comedy personae, then, so 'timeless' that they failed to reflect contemporary society? Clearly, this is too absolute a claim. With reference to Menander, for instance, Michael Anderson (1978:31-32) makes the following qualification:

New Comedy teems with stock characters, some of them, like the crafty slave, the boasting soldier and the aged crone, growing out of the familiar characters of Old Comedy, others, like the hero and the freeborn heroine, transposed (and a little transformed) from the tragic genre. Probably only a minority-like the parasite who feeds at the tables of the rich or the hetaira with her magnificent establishment-owed their particular and distinctive form to the social conditions of the day.

Anderson thus identifies three models that shaped New Comedy characterisation: Aristophanic stock types, pseudo-Euripidean heroes, and figures from contemporary society. For my present argument, I would like to emphasise the first. Although popularised and immortalised by New Comedy, stock characters (and etymologised names) were not 'invented' by New Comedy poets: they had, in a somewhat rudimentary form, already been customary in Old Comedy. In addition to individualised personae based on historical figures, Aristophanes also created etymologised characters such as Dikaiopolis ('Just to the City', or 'He of the Just City') ${ }^{19}$ in Acharnians, Strepsiades ('Twister') in Clouds, and Lysistrata ('Disbander of Armies') in the eponymous comedy of 411 . Moreover, stock types such as the bomolochos or buffoon (e.g. Euelpides in Birds), spoudaios or serious visionary (e.g. Lysistrata), poneros or ingenious improviser (e.g. Philokleon in Wasps), and alazon or braggart (e.g. the Paphlagonian in Knights) are to be found in all Aristophanes' extant plays (cf. Whitman 1964:26-30, 47; McLeish 1980:53-56).

Indeed, such was the influence of Aristophanes' typology that it has even been acknowledged by Aristotle (who, at least in the extant Poetics, does not appear to be interested in Old Comedy). Victor Castellani persuasively argues that Aristotle, in writing about human typology (e.g. in his Nicomachean Ethics, Politics, and Rhetoric), owes a large debt not only to the drama of his own day, but also to Aristophanes (Castellani 1990:22-28).

In Aristophanes, however, there is one additional category of characters which has become the hallmark of Old Comedy, but which would not survive Middle

19 Lowell Edmunds (1980:1) has argued that 'Dikaiopolis' was probably based on the name of an historical person. But this is rather immaterial (Dikaiopolis who?) in view of the obvious typological implications of the etymologised name. 
Comedy. Aristophanic personae frequently portray historically identifiable late fifth-century individuals of whom the historicity is attested in contemporary or near-contemporary sources, historiographic (e.g. Thucydides) or otherwise (e.g. Plato or the Attic orators). Such personae would include the general Lamachos in Acharmians, the populist politician Kleon (barely disguised as the uncouth Paphlagon) in Knights, the philosopher Socrates in Clouds, and the tragedians Aeschylus and Euripides in Frogs. Moreover, personal invective in Aristophanes is often directed at historically identifiable public figures. Kleisthenes, for instance, is regularly ridiculed for his perceived effeminacy ${ }^{20}$ (apart from appearing as a gay character in Women at the Thesmophoria Festival). Kleonymos is satirised for his reputed cowardice, 21 Hyperbolos for being an arch-parvenu. 22 Aristophanic comedies thus tend to be chronologically and geographically restricted by the individualised nature not only of some dramatis personae, but also of numerous targets of invective scattered at random in his plays.

It is claimed by Pseudo-Xenophon (Constitution of the Athenians 2.18) that the stock victims of comic satire were generally either rich or well-born or powerful. Even if the author's motives for making such a statement may be ideological, the claim itself is psychologically plausible: satire, scurrility and invective thrive when aimed at well-known public figures. This must especially have been the case when the Athenian individual fictionalised into a stage persona, or the victim of random comic abuse, was actually sitting in the audience at the Dionysia or Lenaia festival in question. Let me illustrate this with two examples. First, it is reported by Aelian (Variae Historiae 2.13) that at the performance of "a play in which Socrates' name was frequently uttered",23 foreigners were whispering "Who is this Socrates?", whereupon the historical Socrates duly stood up "and remained in full view for the duration of the play" (Dover 1967:27). Aelian's story might be anecdotal, but it serves to remind us that it is not unlikely that Socrates, as a conscientious citizen, actually attended the performance of Clouds in 423 B.C. The second example concerns Aristophanes' bête noire, the tanner Kleon, to whom metatheatrical reference is made more than once. In Acharnians 299-302, for instance, the Chorus appears to be foreshadowing the attack Aristophanes would deliver against Kleon in Knights. ${ }^{24}$ In the production of Knights a year later, in 424 B.C., the persona Demosthenes claims that the mask-makers were afraid to provide a realistic mask (of

20 E.g. Achamians 118, Knights 1373-1374, Clouds 355.

21 E.g.Achamians 88, Clouds 353-354, Wasps 19-23, Peace 446, 673-678, Birds 1473-1481.

22 E.g. Knights 739, Clouds 551-558, 1065, Peace 681-692.

23 It is generally assumed that the allusion is to Aristophanes' Clouds, performed at the Dionysia of 423 B.C. It should, however, be borne in mind that Socrates was also satirised in other comedies, notably in Ameipsias' Konnos (also performed in 423).

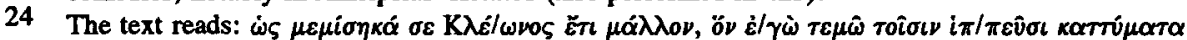
("For I've come to hate you [Dikaiopolis] even more than Kleon, whom I'm going to cut up as soles for the Knights' shoes"). The metaphor of leather helps to identify-and denigrate-the banausic occupation of Aristophanes' target; the reference to "the Knights" anticipates the title of, and the identity of the Chorus in, the poet's next play. 
Kleon) for the actor playing the Paphlagonian (vv.230-233); shortly prior to that,

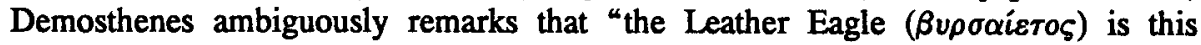
Paphlagonian here" (v.203), possibly pointing at Kleon, as the real-life 'Paphlagonian', in the audience. ${ }^{25}$ At any rate, these references to Kleon would have gained in effect if he was actually sitting in the front seats.

Thus an unrepeatable interaction between the authorial persona and the victim of his invective was created. The dynamics of this process were such that there was nothing comparable in any other genre: even the most vicious invective in Juvenal's satires, for example, was mediated by the text; the unmediated immediacy of a live performance could not be recreated. Such immediacy presupposed that the victims of Aristophanic satire should be alive, and in Athens. For that reason, politicians in exile, or in Hades, were generally exempted from comic abuse. ${ }^{26}$ But for that reason, also, it would prove next to impossible to resuscitate Aristophanes' individualised characterisation in later ages.

The audience would, of course, have found it more difficult to identify emotionally with the foibles of a particular individual than with those of a universalised type, as in tragedy or New Comedy. But this is exactly the point: comic satire is not supposed to elicit empathy, but the contrary. ${ }^{27}$ Plato's Socrates, for one, had no doubt that Aristophanes' caricature of him in Clouds substantially contributed to the diabole that would ultimately lead to the formal indictments against him in 399 B.C. (Apologia 19c).

Having provided examples in support of the rather obvious claim that Aristophanes' targets were not mere figments of his imagination, I must hasten to add a number of caveats, all of which may serve to put the generic idiosyncrasies of Old Comedy, of its poetics and its public, into perspective.

25 Although Knights as a whole is clearly a savage attack on Kleon, his name is mentioned only once in the play (v.976).

26 The convention of de mortuis nil nisi bonum was, however, not absolute. A spectacular exception is provided by Aristophanes' vilification of Kleon in Peace 752-760. This passage, containing unfavourable comments by the Chorus on Kleon's personal hygiene, with particular reference to his genitalia, is an almost verbatim reproduction of the parabasis of Wasps (vv. 1030-1037). Between Wasps (422 B.C.) and Peace (421 B.C.), however, Kleon had died in action near Amphipolis. Yet "more abuse is directed at him in Peace than at any living politician" (Sommerstein 1985:137). Such vilification of the dead rankles, even in a genre as outspoken as Old Comedy. Sixteen years later, Kleon would still haunt Aristophanes' underworld in Frogs-but by now relegated to a mere prosecutor with whom the Landladies threaten Dionysus alias Herakles (vv.569, 577-578).

27 It is customary to distinguish between Horatian satire, eliciting "wry amusement", and Juvenalian satire, evoking "contempt, moral indignation, or an unillusioned sadness at the aberrations of humanity" (Abrams 1985:167). With reference to Ben Jonson's Volpone and The Alchemist, Abrams (1985:28) judges that the foibles of the swindlers and their victims are depicted as "grotesquely ludicrous rather than lightly amusing". Although both types of satire occur in Aristophanes, I am here thinking primarily of the second type, the saeva indignatio of Juvenal. 
My first caveat concerns generic expectations. However politicised Aristophanes' plays may be, he is a poet, not an historian. As Aristotle has reminded us, there is a generic difference between 'poetry' and 'history' (Poetics 1451a-b). The poet is not limited by "what actually happened", but liberated by "what could conceivably happen in terms of probability and necessity". 28 The historical Socrates perforce becomes a fictionalised persona on stage, the authorial persona acting as a juggler mediating between historical truth and comic fantasy. Moreover, whereas the tragic poet was bound by a mythological framework, the poet of Old Comedy had no such constraints. ${ }^{29}$ Thus, owing allegiance neither to history nor to mythology, he could sacrifice historical veracity for comic effect, for good-natured heckling, or even for deliberate misrepresentation. When Aristophanes ridicules Kratinos' hair-style (Knights 531-534), for instance, or Peisander's eyebrows (Peace 395), it probably represents no more than harmless mirth, and should not be taken as the last word on their physiognomy. When he ascribes an implausibly exaggerated role in the genesis of the Peloponnesian War to the deceased Perikles (e.g. Acharnians 528-534, Peace 603-628), it should be taken with a pinch of salt. When, however, he crassly targets Kleon's anatomy, ${ }^{30}$ or his rapacity, it is not funny any more. These are no mere jibes, but a declaration of war, vindictive and malicious. Such passages thus contain examples of, at best, grotesque exaggeration or, at worst, wilful misrepresentation, and should be used as 'historical sources' only with circumspection. 31

The second proviso concerns a point already raised in connection with $\mathrm{New}$ Comedy:32 overlapping between historical individual and universal type. A case in

28 Aristotle is, of course, distinguishing between 'fiction' and 'non-fiction' in general, not between, say, historiography and lyrical poetry. If Aristotle had been thinking of the plots of Old Comedy, he would probably have dispensed with the criterion of 'probability' and 'necessity' altogether in favour of pure fantasy and imagination.

See n. 2 above.

30 See n.26 above.

31 In attempting to account for the extent of Aristophanes' animosity towards Kleon, it is customary to distinguish between two motives. The first could be called ideological (i.e. the opposition between a pro-peace poet and a warmongering, rabble-rousing, opportunist homo novus); the second aesthetic and personal (a vendetta occasioned by Kleon's attempt to indict the youthful Aristophanes after the latter had allegedly, in 426 B.C, abused his comic licence in Babylonians by ridiculing the demos). The allusions to this legal wrangle in Acharnians 377382 and 502-503 are so obviously autobiographical that one could simply ascribe them to the author instead of, as literary convention will have it, the 'authorial persona'. A third motive can be identified, at the intersection of the public and the personal. In Der Gerber Kleon, a study of the locality of Kleon's inherited tannery, Hermann Lind argues that Aristophanes' emphasis on Kleon's occupation bespeaks not only social condescension, but also olfactory displeasure. As fellow-demesman of Kleon in Kydathenaion, Aristophanes would have been irritated on a daily basis by the smell of Kleon's tannery and the fact that it polluted the brook of the Eridanos (Lind 1990:94-102). Edmunds (1987:61) mentions the further consideration that Kleon, as fellow-demesman, was in a position to cause difficulties for the young Aristophanes during his dokimasia.

32 See n.16 above. 
point is the depiction of Lamachos, satirised especially in Acharnians as unreasonably militant (566-625, 959-968, 1071-1149, 1174-1226) and even peculous (597-617). Now we know from Thucydides that the real Lamachos was a public figure of no little renown in late fifth-century Athens. As elected strategos, he was a signatory to the Peace of Nikias in 421; later, he commanded his troops with distinction in Sicily, where he was killed in action (Thucydides 6.101.6). By all accounts, he died a poor man (Plutarch Nikias 15.1). In Aristophanes, however, the fictionalised Lamachos, although probably recognisable from his mask, becomes little more than a faceless miles gloriosus, the earliest extant literary example of an alozon type that would later reappear in Plautus' eponymous play, ${ }^{33}$ and yet later, in caricaturised form, in Bernard Shaw's Arms and the Man (Major Sergius Saranoff). ${ }^{34}$ Thus, faimess towards a prominent politician (which wasn't Aristophanes' forte in the first place) is sacrificed for the sake of typological burlesque.

In the third place, the public profile of Aristophanes' targets should be qualified. A distinction should be drawn between Athenians such as Socrates, Aeschylus, Euripides and Agathon who are fictionalised as personae in Aristophanes' plays and thus become indispensable to the respective plots, and those, on the other hand, whose alleged foibles are ridiculed in passing. The former category perforce consists of well-known public figures: the positive reception of the play in question depended on their fictionalised counterparts, even if comically distorted, being recognised by the public. In the latter category, the public standing of the ridiculed citizen should be inferred only with caution, especially if Aristophanes is our only source for the person's alleged vices. ${ }^{35}$ Let us take the example of Ariphrades (Ariphrades who?), made a laughing-stock in Peace 883 and elsewhere. The gist of the exposé is that he is credited with nothing less earth-shattering than a proclivity for cunnilingus. We do not know what Aristophanes' source, if any, for information of such a rather private nature was. At any rate, it doesn't matter. If Ariphrades was anything but a nonentity, we are not told so elsewhere-unless he was the comic poet mentioned by Aristotle (Poetics 1458b31). Had he been a citizen of public prominence, his public vices, as perceived by Aristophanes, would have been exposed to ridicule. A similar scepticism is called for when evaluating the public prominence of, say, the slave

33 Both Aristophanes' strategos and Plautus' miles are alazon types. However, a distinction can be drawn, as David Konstan (1983a:30 n.32) remarks, between the role of the citizen general in Old Comedy and that of the foreign mercenary in New Comedy.

34 In fact, the miles gloriosus type was "still going strong" in Chaplin's Great Dictator (Frye 1973:163). For a discussion of the function of this type in western comic literature, see Hanson 1965:51-85.

35 The two categories can, obviously, overlap. When Socrates, for instance, is caricaturised in Clouds, the whole plot hinges on his comic counterpart being recognised. When, however, allusion is made to him in plays where he isn't depicted as persona (e.g. in Wasps, Birds and Frogs), even a non-Athenian with no knowledge of local intellectual fashions could still have appreciated the play in question as a whole. 
Exekestides (thrice targeted in Birds), or the oracle-monger Diopeithes (mentioned in Knights 1085, Wasps 380, Birds 988).

For my fourth and fifth caveats, I am indebted to a perceptive article by Stephen Halliwell (1993: 321-340), in which he questions the assumption "that comedy was actively and potentially involved not only in the reflection but also in the creation of publicity" (1993:322), and concludes that “... many comic targets continued to be popular and successful in the very areas and activities in which they were ridiculed in the theatre" (1993:339). A clear-cut example of this paradoxical phenomenon is provided by the fate of the populist politician Kleon. Aristophanes was awarded a first prize for Babylonians (426 B.C.), Acharnians (425), and Knights (424)-highly politicised plays containing vitriolic attacks on Kleon's person and his politics. During that very period, however, Kleon.was highly influential in the ekklesia, and he was annually re-elected as strategos between his maverick success at Pylos (425 B.C.) and his death in 422 (Thucydides 5.10.9, 5.16.1). ${ }^{36}$

In making my fourth qualification concerning the lampooning of individuals in Old Comedy, then, I am in general agreement with Halliwell's view that there does not appear to be a causal relationship between the frequency or vehemence of comic invective against a public figure, and the same figure's public popularity. ${ }^{37}$

My fifth proviso concerns Aristophanic prejudice. It has already been mentioned in connection with his treatment of Kleon. Here, however, I want to deal with a possible corrective for perceived Aristophanic one-sidedness: comparison with other

36 This apparent anomaly can be resolved by assuming that Aristophanes' audience was more sophisticated and discerning than the average citizen attending the ekklesia (Barrett 1964:25). Such an assumption would appear to carry conviction in view of the obvious degree of literary awareness necessary for an appreciation of Aristophanic paratragedy (i.e. especially in Acharmians, Women at the Thesmophoria Festival, and Frogs). On the other hand, one should consider demographic realities in late fifth-century Athens, in so far as these can be reconstructed. It can be assumed that many thousands of adult male citizens would be unavailable for attendance of either the more or less weekly ekklesia or the seasonal drama festivals, on account of old age, ill-health, business commitments, lack of interest, military duty abroad or, in the case of citizens of rural demes, the distance to the city centre. In the case of drama festivals, of course, not all of the spectators in a capacity crowd of c. 14000 at the Theatre of Dionysos would be male Athenian citizens. In view of demographic considerations such as these, therefore, it should be stressed that the groups attending the elklesia and the theatre, respectively, should not be thought of as mutually exclusive in any absolute sense. If a fair measure of shared identity is assumed between a typical comedy audience and those attending an average meeting of the ekklesia, I would suggest a further solution for the anomaly of Kleon's political popularity at a time when he was clearly unpopular with the drama jury, and probably with Aristophanes' audience as well: the persuasive powers of rhetoric. It is not unlikely that the very same people who succumbed to Aristophanes' poetical rhetoric and were thus swayed to applaud the poet and jeer at his target, would a week later elect that selfsame target as strategos, swayed by his demagogic rhetoric. The notorious fickleness of the Athenian populace would have seen to that.

37 If there is any validity in the claim of the Platonic Socrates (Apologia 19c) that the public prejudice against him was exacerbated by the theatre public's exposure to his caricature in Clouds, then Socrates would be the exception that validates Halliwell's 'rule'. 
Old Comedy poets. If Aristophanes is our only source, and if, moreover, we take the frequency and tone of his reference to Athenian individuals as indicative of their actual prominence, we might fall prey to some serious distortion. Halliwell (1993: 330) contends that, for example, "... individuals of the Aristophanic conspiciousness of Lamachus and (probably) Agathon are not mentioned in the remains of any other comic poet". Even if allowance is made for the fragmentary nature of non-Aristophanic Old Comedy sources, Halliwell's comment should caution students of Aristophanic caricature, again highlighting, as it does, the dangers of taking Aristophanes at face value.

Halliwell's most compelling example concerns the public profile of Kleonymos, frequently made the target of schadenfreude by Aristophanes for his presumed cowardice on the battlefield at Delion in 424 B.C. 38 "If, for example", Halliwell (1993:331) ponders, “Cleonymus' alleged act of $\dot{\rho} \iota \psi \alpha \sigma \pi i \alpha$ was as much of a scandal as most Aristophanic scholars have been prepared to believe, why does no other poet than Aristophanes seem to have made very much of it?". The evidence does not permit us to conclude whether Kleonymos' personality lent itself to such ridicule, or whether Aristophanes had a personal axe to grind. What we can ascertain, however, is that the intertext of other Old Comedy poets, albeit frustratingly fragmented, is sometimes a useful tool in deconstructing the authority of Aristophanes' text.

Conversely, it might be asked why Alkibiades, whose personality lent itself superbly to caricature, was not targeted more often and more vehemently by Aristophanes. Between 415 and 407, Alkibiades' absence from Athens could account for the lack of attention he receives from Aristophanes; moreover, the decree of Syrakosios (415) would have inhibited comic playwrights. ${ }^{39}$ But between c. 427 , when the youthful Alkibiades started catching the limelight, and his election as strategos for the Sicilian expedition in 415 , surprisingly little reference to him is made by Aristophanes.

The five caveats dealt with above all serve to qualify the nature of Old Comedy invective and caricature, without detracting from the fact that Old Comedy characterisation differs in fundamental respects from that of New Comedy. Characterisation in Graeco-Roman comedy, between Aristophanes and Terence, would thus provide two distinct models for later imitators or adapters to choose from: individual (prominent in Old Comedy) versus type (popularised by New Comedy).

Types, as universal, tend to be more accessible to all ages, and thus to transcend the limitations of cultural specificity inherent in Aristophanes' satirical depiction of his contemporaries. Socrates, for instance, was a unique fifth-century individual-so unique, in fact, that no later writer of comedy could resurrect a literary clone of him with any conviction-whereas a curmudgeonly senex or a conniving servus is

38 See n.21 above.

39 For the historicity of Syrakosios' decree, see Atkinson 1992:56-64 contra the agnostic view of Halliwell 1991 :48-70. 
timeless. The ancestry of Falstaff or Sir Toby Belch, for example (or of Wodehouse's Jeeves), is therefore to be traced to Plautus rather than to Aristophanes. 40

When the heirs of New Comedy created stereotype characters in Renaissance and post-Renaissance England, their debt to their models was evident on three levels. In the first place, some stock types were directly borrowed. This is implicitly acknowledged, for instance, in Ben Jonson's The Alchemist (1610), where the following information is provided in the Prologue (vv. 5-9):

Our scene is London, 'cause we would make knowne

No countries mirth is better than our owne.

No clime breeds better matter, for your whore,

Bawd, squire, impostor, many persons more,

Whose manners, now called humors, feed the stage.

Secondly, contemporary 'types' begging to be satirised, were exploited. Thus the stock Englishman with a monocle, an exaggerated Oxford accent, and a defective sense of humour, became the butt of nineteenth-century comedy, whereas the tight-lipped Sheriff who let his gun do the talking, was generated by 'Westerns' in the twentieth century (Abrams 1985:179).

Thirdly, artificial compound names based on etymology would reappear: Sir Politick-Would-be and Sir Epicure Mammon in Ben Jonson, for instance, or Sir Pertinax MacSycophant in Macklin's 1781 comedy of manners, The Man of the World (Hare 1978:126, 137-138), or Lady Sneerwell in Sheridan. 41 Thus the characterisation and nomenclature popularised by New Comedy would prove, on account of their universal appeal, to have a productive intertextual nachleben.

By comparison, Old Comedy's proclivity for satirising historical individuals would severely hamper its post-Renaissance nachleben. As theatre audiences came to represent a much smaller percentage of the population of big European cities than was the case in classical Athens, the likelihood of a comic target actually being in the audience diminished. Consequently, it became more difficult to recreate the unique dynamics between drama text, target and audience that obtained in Aristophanes' Athens. Nevertheless, a comic dramatist with Aristophanic leanings still had a choice: either satirise, say, Kleon or Alkibiades (in which case very few members of an average audience would be able to appreciate it), or target a contemporary politician like Major or Thatcher (in which case the topicality of the

40 In all faimess to Aristophanes, his scheming Xanthias in the first part of Frogs is a convincing forerunner of the servus callidus. But he does not yet attain to the stature of an architectus such as Plautus' Pseudolus, Chrysalus (in the Bacchides) or Epidicus, all of whom manipulate and orchestrate the plots of the comedies in which they feature. For the nachleben of the 'tricky slave' in English comedy, see Sampson 1983:91-101.

41 In fact, such names also occur in allegorical fiction. In The Pilgrim's Progress, for instance, Bunyan describes how Christian, on his way to the Celestial City, encounters a "Mr. WorldlyWiseman" from "the Town of Carnal-Policy". 
joke-for all but historians-would gradually diminish and fade into oblivion after, at most, a decade).

The nachleben of Old Comedy characterisation, such as it was, is typified by two trends. First, with very few exceptions, 42 it would be delayed till centuries after the Renaissance. Secondly, it would frequently be channelled into new subgenres of humour outside formal comedy.

It was only in the nineteenth century that a form of comic characterisation recognisably akin to Aristophanes was revived on a broader scale. In the course of that century, the critic W.D. Howarth (1978b:5) notes, a new form of comedy would develop which was "... based ... on an increased awareness of the social and political interests of a middle-class audience ...". This would result in "a move away from the generalized 'types' of neoclassical comedy, in favour of individuals with a well-established social identity". In his treatment of British comedy, Arnold Hare dates this trend to the latter half of the nineteenth century, crediting its advent to Tom Robertson. In plays like Society (1865) and Castle (1867), Robertson began "... the long haul back from stereotypes to individual characters based recognizably on the foibles of the human being(s) we know and live with ..." (Hare 1978:138).

In the twentieth century the popularity of 'Aristophanic' individualisation has been accelerated especially by cabaret and by the media. In Britain, The Goon Show and The Monty Python Show contain elements of surreal Aristophanic satire (Brandt 1978:178-179); locally, Pieter-Dirk Uys' mimicry of public figures is true to the spirit of Aristophanic lampooning, as are newspapers cartoons. ${ }^{43}$ In the U.S.A., the self-confessed Republican P.J. O'Rourke (All the trouble in the world) does Aristophanes proud when he gores the vice-president or performs a Clintonectomy on Washington, D.C. Moreover, Aristophanes' derogatory nicknames for Kleon ('The Eagle of Leather', 'Old Kerberos') and others are echoed in names such as 'Die Groot Krokodil' for P.W. Botha, 'Magnus P.I.' for an erstwhile Minister of Defence, and 'Womandela' or 'The Vice Minister' for a certain Ms. Madikizela.44

Such modern forms of 'Aristophanic' lampooning, sadly, suffer from the same drawback as their model: the cultural and chronological specificity of their allusions. As the public profile of a politician diminishes, so does his topicality. Pieter-Dirk Uys, like Aristophanes, has to adapt name-dropping catch-phrases the day before a performance; a month later the joke could be stale. Similarly, a modern satirist has to consider the cultural leanings of his audience (as Aristophanes had to do to accommodate non-Athenians at the Dionysia, in contrast with the Athenians-only

42 See n.3 above.

43 Sir Kenneth Dover (1967:17-22) has argued for an analogy between the art of the ancient mask-maker and the art of the modern cartoonist, pointing out cultural features (e.g. a pipe) as well as natural features (e.g. a moustache) by which a target can be identified.

Local wags are quick to cash in on public faux pas or other manifestations of a talent for politics, as witness neologisms such as Bantubonkers Holomisa, Hernia Kriel, or the Health Freak (Dr. Zuma). And in pre-rainbow times there were Piet Promises and Hennie 'Flinkdink' Smit. In all such cases Aristophanic improvisation is a recommendation. 
Lenaia). The average audience in Reykjavik or Ulan Batur is not likely to comprehend allusions to R.D.P., for instance, or 'Vaalies', or 'Souties'.

\section{$4 \quad$ Narrative structure: plots and themes}

Post-Renaissance adapters would, moreover, have found Aristophanes inaccessible in terms of theme and plot. His plays tend to display a duality between what may be termed political reality and comic fantasy. In his world of 'magic realism', to apply a term usually reserved for a subgenre of the twentieth-century novel, the pole of 'realism' is represented by the depiction (usually with comic exaggeration) of the socio-political realities of late fifth-century Athens. ${ }^{45}$ Thus the theme of peace, as dramatised (advocated?) with varying degrees of urgency in his three 'peace plays' (Acharnians, Peace, Lysistrata), is very solidly anchored in the realities of an Attica which is ravaged by the Peloponnesian War while its citizens are spurred on to a continuation of the war by the demagoguery of war-mongering politicians such as Kleon. The shortcomings of the Athenian jury system, as satirised in Wasps, is firmly rooted in the historical reality of Athenian egalitarian jurisprudence. The potentially harmful effects of sophism on the Athenian education system, though unjustly ascribed to the fictional Socrates in Clouds, are based on a very real contemporary debate about moral theory and paedagogical practice. Indeed, such is the degree to which Old Comedy reflects socio-political realities that the ekklesia scene in Acharnians, as well as the depiction of the jury system in Wasps, for instance, has been used (though not without reservations) as an 'historiographic' document. Even Birds, in many ways Aristophanes' most escapist comedy, has been taken to reflect, in remarkably detailed fashion, the realities of Athenian imperialism in 414 B.C. 46

So much for realism. The obverse, however, is that every extant Aristophanic comedy contains an indispensable element of fantasy, called "freedom from everyday logic" by Anderson (1978:24). However firmly the geo-political allusions in Aristophanes' plays may be rooted in the reality of war-time Attica, the plots themselves invariably involve the phantasmagoria of More's Ou-topia or Hope's Ruritania.

In spite of the apparently fortuitous directions in which Aristophanes' fancy takes him, critics have detected a common pattern applicable to all his extant comedies, according to which the vicissitudes of the comic hero(ine) can be systematised. Dobrov (1988:16) regards Old Comedy plays as "bipartite", the first "movement" consisting of an agon, the second being a sort of revue play. The plays commence, as McLeish (1980:64) notes, with the hero in dismay, alienated from the

45 See n.7 above.

46 The original 'allegorical' interpretation of possible political allusions in Birds dates back to the German critic J.W. Süvern in 1826 . In recent years, however, the thesis has been forcefully restated, refined and supplemented by Arrowsmith 1973, Katz 1976, and Vickers 1995, the latter taking Pierre Brumoy's 1730 work as point of departure. 
normal world. Accordingly he/she devises a fantastic scheme by which natural laws are inverted and normality restored. Thus, in Acharnians, the war-weary Dikaiopolis sends the semi-divine Amphitheos on a humanly impossible embassy to conclude a peace treaty with Sparta. In Peace, Trygaios is whisked away to the palace of the gods on the back of a recalcitrant dung-beetle. In Birds, Peis(th)etairos orchestrates the building of a Cloud City for birds and dissatisfied Athenians, ultimately even usurping the sovereignty of Zeus.

The fantastic mission of the hero figure having been accomplished, nothing much happens further in the play to change the fortunes of the hero. The second part of most extant Aristophanic comedies thus has an 'episodic' nature, ${ }^{47}$ with very little in the way of suspense. Various figures from the 'real' world visit the hero so as to share materially in his success; they are almost without exception driven away, providing for much slapstick humour. Ultimately, with "the restoration of true cosmic order" (McLeish 1980:64), the play ends on a happy note, 48 in keeping with generic convention. ${ }^{49}$ In the concluding celebration scene (a legacy of the probable origin of comedy from the komos or 'procession of revellers'), the comic hero is rewarded with pleasures of a sexual and/or gastronomic nature.

Sifakis (1992:140-142) has devised an even more elaborate scheme, based on the Russian formalist Vladimir Propp's structural analysis of the thirty-four possible 'functions' of folk tales, to systematise the 'narrative structure' of Old Comedy. Sifakis' scheme contains the following sequence of 'functions': (1) Villainy, lack or misfortune; (2) Decision and plan to counteract misfortune; (3) Service or help of a supernatural or quasi-magical agent or helper obtained; (4) Transference; 50 (5) Opposition or obstacles to be overcome; (6) Persuasion exercised in debate; (7) Liquidation of villainy or misfortune; (8) Triumph of hero.

Such, then, is the typical 'narrative structure' of Old Comedy..$^{51}$ As substantiated by the above examples, such a blend between the utter make-believe of a never-never-land, and the concrete realities of late fifth-century Athens, is typically Aristophanic. Moreover, it is uniquely so. It is not surprising that, on the whole, such an unusual model has failed to find favour with posterity.

Before discussing the general characteristics of plots and themes in New Comedy, I would like to point out, by way of contrast, three aspects of Aristophanic plots that would greatly hamper his nachleben. First, what Aristotle would later

47 Frogs represents the most noteworthy exception in that the second part contains the agon between Aeschylus and Euripides. It would, presumably, have stretched even Aristophanes' imagination to let a queue of living Athenian mortals visit Hades as hangers-on begging for scraps.

48 The extant copy of Clouds is exceptional in that the ending is, at best, ambiguous and, at worst, reminiscent of tragedy.

49 Aristotle Poetics 1453a30-39.

50 'Transference' refers to change in geographic location, e.g. when Trygaios is transported to heaven in Peace. This category is not applicable to Knights, Clouds or Wasps.

51 The complexities of the formal structure of Old Comedy, which were also instrumental in hampering its nachleben, will not be discussed in this paper. See p.163, item 5 above. 
commend as "necessity and probability" in the plot structure of tragedy (Poetics 1451a36-b9), is almost totally absent in Aristophanes. The entertainment value of his flights of fancy runs the risk of being neutralised by lack of cohesion, by non sequiturs, especially by the somewhat tedious concatenation of inconsequential, 'episodic' scenes in the second half of his plays (Birds has fourteen between first parabasis and exodos). Secondly, suspense is thus forfeited. For suspense to be effective, in any genre, the author must create certain expectations in the reader/spectator-expectations which can then be fulfilled, or partly fulfilled, or subverted, in any number of ways. This, however, presupposes a modicum of structural cohesion. Since cohesion is the very element which is lacking in Aristophanes, he leaves little room for suspense or for a dénouement proper. Potential post-Renaissance imitators were not slow to notice this structural defect. In the third place, as Niall Slater points out, Aristophanes' fixation on Athenian politics had no appeal outside Athens; there are no records of any performances outside the city after his lifetime. Menander's young lovers, on the other hand, appealed to Greek-speaking audiences from Athens to Alexandria to Syracuse (Slater 1987:6).

The evolution of the comic genre from Old through Middle to New Comedy could be reconstructed as a gradual affair, and fragments of Middle and early New Comedy would justify the critic to make much of the continuity of ancient comedy, as Dover (1987:213-214), for instance, does. Judged by extant plays, however, differences between Old and New Comedy plots appear to dwarf elements common to both genres. Between the last extant Old Comedy play by Aristophanes (Frogs, 405 B.C.), and the only extant example of an unfragmented Greek New Comedy play (Menander's Angry Old Man, 316 B.C.), a paradigm shift took place. A spectator brought up on Aristophanes would have experienced culture shock when, hypothetically, exposed to Menander a century later.

In which respects, then, did a typical New Comedy plot deviate from its Old Comedy counterpart? By which thematic preoccupations was it differentiated from Aristophanes' world of 'magic realism'? Firstly, the shift from Old to New Comedy was one from the agora to the oikos, from public to private. The agora was the symbolic focal point of Aristophanic comedy, where even seemingly private concerns (such as Dikaiopolis' private peace treaty in Acharnians) had public reverberations. The oikos or household, on the other hand, was the locus of domestic relations, a private microcosm where, as Michael Anderson has pointed out, money and sex ruled supreme. "One is the most abstract medium of transaction in the human world", Anderson argues, "and the other the most personal one. Comic dramatists have never ceased to find it amusing that, within limits, one can be substituted for the other" (Anderson 1978:29). In his "social analysis" approach to Roman comedy, David Konstan (1983a:21) has a comparable view of the role of money, describing it as "a solvent of traditional social relations".

The 'sexual' pole of Anderson's polarity finds expression in thwarted love affairs with, of course, a happy ending for the comic hero(ine). In part, this trend could be traced to Euripides, some of whose later plays (e.g. Ion, Helen) could be called 'romantic tragicomedies'. In his Vita of Euripides, Satyros identifies the 
following motifs New Comedy borrowed from the Athenian iconoclast: "... quarrels between husband and wife, father and son, servant and master, or situations involving sudden change of fortune, substitution of children, violation of girls, and recognition by rings and necklaces; for all this is really the mainstay of New Comedy, and it was Euripides who perfected it" (quoted by Dover 1987:216; cf. also Sandbach 1977:58).

Despite the narrower focus on 'mere' domestic relations, a wide range of thematic and structural possibilities is depicted in the twenty-seven extant examples of Graeco-Roman New Comedy. For the purpose of this article, however, a plot typical of New Comedy will have to be abstracted as a sort of common denominator. The following resumé by Victor Castellani (1988:54) provides as good a starting point as any:

Most often the plot involved the difficulties in love of a young man who could neither marry (if she was free) nor purchase (if she was a slave) the girl he loved. Blocking his success could be his parents, her parents-or her owneror a rival lover. Sometimes it was simply his poverty. By intrigue or by the fortunate discovery that she was a long-lost cousin, or at least the long-lost daughter of a family friend, boy almost invariably got girl, though seldom before learning an edifying lesson or two.

Castellani's resumé could be abbreviated even further. In 1912 C.R. Post (quoted by Konstan 1983a:28) reduced the formula for New Comedy to a mathematical equation,

$$
w \frac{(x-y)}{z}=x+y,
$$

where $x-y$ represents the separated couple, $x+y$ the united couple, $z$ the obstacles to their union, and $w$ the mode of overcoming the obstacles.

Mathematicians may grimace at the licence Post allows himself with multiplication and division functions, classicists may frown at such quantification of the unquantifiable, Terence may turn in his grave because no provision has been made for his double plots. Moreover, every second New Comedy play contains permutations of and refinements to societal codes that go beyond the simplicity of the equation, as Konstan (1983:20-21, 26-29) illustrates with examples. Nevertheless, Post's formula has the merit of being a great mnemonic.

As noted, the letter $z$ in Post's formula symbolises the obstacles to the lovers' union, the 'blocking agents' such as relatives or pimps. In a sense, however, these agents were not acting alone. They were in cahoots with Fate, or Chance, or Fortuna. Since a personalised Tyche was actually worshipped as a deity in Hellenistic times, a word should be said about her role in New Comedy. On the one hand, she was responsible for allotting all the typological personae their parts, from slave to wealthy landowner. On the other hand, she not only saw to "minor readjustments in the pattern-an unexpected legacy here, a rescue from servitude by a long-lost father there ..." (Anderson 1978:27-28), but also "... brought the 
characters' problems, after amusing complications, to a pleasing and convincing solution by compromise, by discovery, or by sheer good luck" (Castellani 1988:55).

Tyche would be resurrected in Renaissance drama, especially in Italy, thus underlining the durability of yet another aspect of New Comedy. In accounting for the superficial optimism of Italian Renaissance drama, Felicity Firth (1978:71) explains the dramatic function of Tyche:

The goddess Fortuna has to rear her head in every godless age as a powerful external force antagonistic to man, fabricated in the absence of evil to provide him with a worthy adversary, whose defeat will prove to him his own resourcefulness and virtù. Theatrically she is a success; she replaces the villain.

The plots and themes of New Comedy were, indeed, a far cry from Aristophanes. Two characteristics of New Comedy plots and themes especially contributed to their lasting impact and adaptability. First, it is love that makes the world go round, not politics, as Aristophanes seems to have thought. “There is no play of Menander's without love", Ovid would grumble three centuries later (Tristia 2.369). Yet nineteen centuries later Nietzsche would pooh-pooh both Euripides and Menander as examples of "bourgeois mediocrity" (The Birth of Tragedy, ch.11). It was this very preoccupation with middle-class concerns, however, that would guarantee New Comedy a productive nachleben. Romantic love, in whatever form, will always sell well. In a world where love often goes wrong, what Northrop Frye (1973:44) calls "the Cinderella archetype" provides a soothing escape from reality. Although happy endings may not be "true", they remain "desirable" (Frye 1973:170).

There was no romanticism in Aristophanes' plots. Fantasy, yes, plenty. Sex, yes, lots of it, crudely depicted, leaving little to the imagination. But love, no. Had he only applied the 'boy-meets-girl' formula, Old Comedy instead of New would have been regarded as the true progenitor of Mills \& Boon. For having escaped such an ignominious nachleben, Aristophanes would, one supposes, give a sigh of relief in his grave.

Secondly, the convention of a recognition scene in New Comedy created a model for a number of present-day literary genres dependent on suspense.

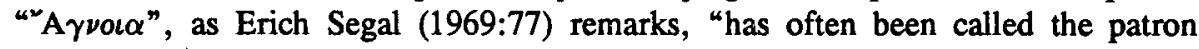
goddess of New Comedy". The resolution of agnoia or ignorance is accompanied by suspense. An anagnorisis scene, regarded by Aristotle (Poetics 1452a12-21, a29b8) as indispensable to a complex plot in tragedy, provides answers to questions such as: When will mistaken identity or other mysteries be revealed? Under what circumstances? By which agent or process? These are the very questions creating suspense in modern detective novels, whodunnits, and thrillers in general, as well as in corresponding cinematic and television genres. Indeed, in tracing the origin of the modern detective story to the Sherlock Holmes period, Northrop Frye (1973:46) adds the qualification that it developed "as an intensification of low mimetic". In Frye's paradigm, 'low mimetic' includes New Comedy. Further support for such a view is provided by a recent article of John Whitehorne (1993:97-105), in which he interprets Menander's Dyskolos as a detective story. 
It could thus be argued that a number of popular new literary genres have been spawned by the legacy of New Comedy. The most important common factors, in each case, are suspense and love, both of which were lacking in Aristophanes. Such genres were exponentially multiplied by the advent and popularisation of the visual media.

\section{Conclusion}

"The materia poetica is as common to all writers, as the materia medica, to all physicians." Thus Dryden, in the Preface to Don Sebastian (1689), defending himself against a charge of plagiarism.

On a psychological level, Dryden's argument carries conviction. In general terms, he appears to be right. Moreover, his generalisation could be applied to specific genres such as tragedy or New Comedy, in that the plot and characterisation of Medea or Dyskolos would find emulators in later ages. However, it is more problematic to apply Dryden's sententia to Aristophanes. Old Comedy was unique. Of all the literary genres to which archaic, classical and Hellenistic Greek poleis gave birth, it proved, to misquote Aristotle (Poetics 1448b7), $\dot{\alpha} \mu \iota \mu \eta \tau \kappa \omega \dot{\omega} \tau \alpha \tau o \nu$ (least imitable). Every single other mainstream genre between Homer and Lucian would provide models for later adaptation; only Old Comedy lacked the universality which is a prerequisite for a popular nachleben.

I have highlighted some reasons for Aristophanes' limited nachleben. In a nutshell, he was too esoteric. Spectators can identify more easily with a mundane New Comedy hero(ine) like themselves than, for instance, with a unique and eccentric Trygaios flying to heaven on a farting dung-beetle. Moreover, the formula for New Comedy romance and suspense will always sell better than Aristophanes' bipartite plot structure, where unbridled fantasy joins forces, in a marriage of inconvenience, with politician-bashing. Aristophanes' eclecticism was thus his downfall; his very versatility would prove too daunting for his would-be heirs. Gregory Dobrov (1988:16) summarises the diversity of Old Comedy as follows:

The volatile synthesis included broad slapstick, ritual abuse, ceremonial wedding and feast scenes, metrically sophisticated choral song, extended word-play, literary parody, borrowings from tragic form (prologue) etc.

In such a hotch-potch genre, the author is perforce attempting to be all things to all men. As Aristophanes' nachleben has proved, such an ideal is unattainable.

It is, however, possible to conclude on a positive note. In note 3 above I differentiated between the generic heritage of Aristophanes (as manifested in Racine and Shelley), and a more oblique legacy (e.g. that of Jonson and Shakespeare). If the term 'nachleben' is not restricted to conscious emulation of Old Comedy but expanded to include its 'oblique' heritage, the influence of Aristophanes on literature since the Renaissance could be shown to be considerable. At the very least, correspondence between Aristophanes' idiosyncrasies and subsequent trends, fads and movements could be demonstrated. Within such a paradigm, various and 
variegated literary genres and subgenres, as well as other art forms, can be identified as third-generation heirs of Aristophanes. Whenever absurdism or surrealism crops up-be it in Jarry's Ubu Roi, in lonesco, in Sartre, or in Tom Robbins-homage is implicitly paid to Aristophanes. The depiction of the grotesque and the bizarre, whether by Salvador Dali or by Roald Dahl, is reminiscent of Aristophanes. Science fiction could be traced, via Lucian, to the Aristophanic Trygaios or Peisthetairos; utopian (or dystopian) literature, between More's Utopia and Orwell's 1984, echoes the imaginative spirit of Nephelokokkygia. Even the most innovative contribution to narrative fiction of the past four decades, magic realism, is hauntingly Aristophanic: Marquez and Allende, Kundera and Rushdie, are all drawing on the same double impulse that inspired Aristophanes to intersperse reality with fantasy.

What about metatheatre? Cartoons and cabaret? Vulgar humour, farce and slapstick? The list of Aristophanic echoes does, indeed, appear endless. The last word should, perhaps, be given to Alexis Solomos, the director who has done most to re-introduce Aristophanes to modern Greece. Discussing Aristophanes' contemporaneity, Solomos (1974:10) muses:

Were he living today, he would unquestionably frequent, besides zoos, nightclubs and music-halls, puppet shows and circuses; he would have studied the art of the Fratellinis and the Marx Brothers: he would be a Donald Duck fan and Charlie Chaplin admirer.

Down below in Hades, Aristophanes, one imagines, continuing his symposium with Agathon and company, would give a nod of assent.

\section{BIBLIOGRAPHY}

Abrams, M H 1985. A Glossary of Literary Terms. New York: Holt, Rinehart \& Winston.

Anderson, M 1978. The Comedy of Greece and Rome. In Howarth 1978a, 22-39.

Anderson, W S 1995. The Roman Transformation of Greek Domestic Comedy. Classical World 88, 171-180.

Arrowsmith, W 1973. Aristophanes' Birds: The Fantasy Politics of Eros. Arion n.s. 1, 119-167.

Atkinson, J E 1992. Curbing the Comedians: Cleon Versus Aristophanes and Syracosios' Decree. Classical Quarterly 42, 56-64.

Barrett, D (transl.) 1964. Aristophanes: The Wasps, The Poet and the Women, The Frogs. Harmondsworth: Penguin Books.

Berdoe, E 1891. Browning Cyclopaedia. London: Allen \& Unwin.

Brandt, G 1978. Twentieth-century Comedy. In Howarth 1978a, 165-186.

Cartledge, P 1990. Aristophanes and His Drama of the Absurd. Bristol Classical Press.

Castellani, V 1988. Plautus Versus Komoidia: Popular Farce at Rome. In Redmond 1988, 53-82.

Castellani, V 1990. Drama and Aristotle. In Redmond, J (ed.), Themes in Drama 12: Drama and Philosophy, 21-36. Cambridge: Cambridge University Press. 
Chapman, G A H 1983. Aristophanes for All. Acta Classica 26, 41-51.

Dobrov, G 1988. The Dawn of Farce: Aristophanes. In Redmond 1988, 15-31.

Dover, K J 1967. Potrait-masks in Aristophanes. In Westendorp Boersma, R E H

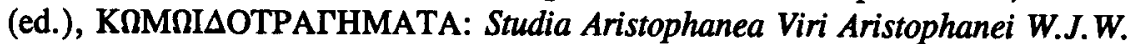
Koster in Honorem, 15-31. Amsterdam: Hakkert.

Dover, K J 1972. Aristophanic Comedy. London: Batsford.

Dover, K J 1987. Greek and the Greeks. Oxford: Oxford University Press.

Duckworth, G E 1952. The Nature of Roman Comedy. Princeton: Princeton University Press.

Eco, U 1987. The Comic and the Rule. In Travels in Hyperreality, 269-278. London: Picador/Pan Book.

Edmunds, L 1980. Aristophanes' Acharnians. Yale Classical Studies 26, 1-14.

Edmunds, L 1987. Cleon, Knights and Aristophanes' Politics. London: University Press of America.

Edmunds, O M (ed.) 1979. The Comedy of Errors. Cape Town: Maskew Miller.

Firth, F 1978. Comedy in Italy. In Howarth 1978a, 63-80.

Frye, N 1973. Anatomy of Criticism. Princeton: Princeton University Press.

Halliwell, S 1991. Comic Satire and Freedom of Speech in Classical Athens. Journal of Hellenic Studies 111, 48-70.

Halliwell, S 1993. Comedy and Publicity in the Society of the Polis. In Sommerstein, A $\mathrm{H}$ et al. (eds.), Tragedy, Comedy and the Polis, 321-340. University of Nottingham.

Hammond, M et al. (ed.) 1970. T. Macci Plauti: Miles Gloriosus. Cambridge, Mass.: Harvard University Press.

Hanson, J A 1965. The Glorious Military. In Dorey, T A \& Dudley, D R (eds.), Roman Drama, 51-85. London: Routledge.

Hare, A 1978. English Comedy. In Howarth 1978a, 122-143.

Henderson, J 1975. The Maculate Muse: Obscene Language in Attic Comedy. New Haven: Yale Univ. Press.

Highet, G 1967. The Classical Tradition. Oxford: Oxford University Press.

Howarth, W D (ed.) 1978a. Comic Drama: The European Heritage. London: Methuen.

Howarth, W D 1978b. Introduction: Theoretical Considerations. In Howarth 1978a, 1-21.

Hubbard, T K 1991. The Mask of Comedy: Aristophanes and the Intertextual Parabasis. Ithaca: Cornell University Press.

Hunter, R L 1985. The New Comedy of Greece and Rome. Cambridge: Cambridge University Press.

Katz, B R 1976. The Birds of Aristophanes and Politics. Athenaeum 54, 353-381.

Konstan, D 1983a. Roman Comedy. Ithaca: Cornell University Press.

Konstan, D 1983b. A Dramatic History of Misanthropes. Comparative Drama 17(2), 97-123.

Levin, H 1986. Notes toward a Definition of City Comedy. In Lewalski 1986, 126146. 
Lewalski, B K (ed.) 1986. Renaissance Genres: Essays on Theory, History and Interpretation. Cambridge: Harvard University Press.

Lind, H 1990. Der Gerber Kleon in den 'Rittern' des Aristophanes: Studien zur Demagogenkomödie. Frankfurt: Peter Lang.

MacCary, W T 1978. The Comedy of Errors: A Different Kind of Comedy. New Literary History 9, 525-536.

McLeish, K 1980. The Theatre of Aristophanes. London: Thames and Hudson.

Redmond, J (ed.) 1988. Themes in Drama 10: Farce. Cambridge: Cambridge University Press.

Sampson, H G 1983. The Phormio Syndrome: The Tricky Slave in English Comedy. In Hartigan, K (ed.), From Pen to Performance, vol. 3, 91-101. New York: University Press of America.

Sandbach, F H 1977. The Comic Theatre of Greece and Rome. London: Chatto \& Windus.

Segal, E 1969. The Menaechmi: Roman Comedy of Errors. Yale Classical Studies $21,77-93$.

Sifakis, G M 1992. The Structure of Aristophanic Comedy. Journal of Hellenic Studies 112, 123-142.

Slater, M 1988. Racine's Les plaideurs-A Tragedian's Farce. In Redmond 1988, 83-97.

Slater, N W 1987. Transformations of Space in New Comedy. In Redmond, J (ed.), Themes in Drama 9: The Theatrical Space, 1-10. Cambridge: Cambridge University Press.

Solomos, A 1974. The Living Aristophanes. Ann Arbor, Michigan.

Sommerstein, A H (transl.) 1978. The Knights, Peace, The Birds, The Assemblywomen, Wealth. Harmondsworth: Penguin Books.

Sommerstein, A H 1985. The Comedies of Aristophanes. Vol. 5: Peace. Warminster: Aris \& Phillips.

Thomson, J A K (transl.) 1965. The Ethics of Aristotle. Harmondsworth: Penguin Books.

Vickers, M 1995. Alcibiades at Sparta: Aristophanes' Birds. Classical Quarterly 45, 334-354.

Watson, R N 1986. The Alchemist and Jonson's Conversion of Comedy. In Lewalski 1986, 332-365.

Whitehorne, J 1993. Menander's Dyskolos as Detective Story. Australian Modern Languages Association 79, 97-105.

Whitman, C H 1964. Aristophanes and the Comic Hero. Cambridge: Harvard University Press. 